\title{
ANIMAL RESEARCH PAPER Effect of breed and pasture type on methane emissions from weaned lambs offered fresh forage
}

\author{
M. D. FRASER*, H. R. FLEMING, V. J. THEOBALD AND J. M. MOORBY \\ Institute of Biological, Environmental and Rural Sciences, Aberystwyth University, Gogerddan, Aberystwyth, SY23 3EB, UK
}

(Received 12 February 2015; revised 31 March 2015; accepted 6 May 2015)

\section{SUMMARY}

To investigate the extent to which enteric methane $\left(\mathrm{CH}_{4}\right)$ emissions from growing lambs are explained by simple body weight and diet characteristics, a $2 \times 2$ Latin square changeover design experiment was carried out using two sheep breeds and two fresh pasture types. Weaned lambs of two contrasting breed types were used: Welsh Mountain (WM, a small, hardy hill breed) and Welsh Mule $\times$ Texel (TexX, prime lamb) $(n=8$ per breed). The lambs were zero-grazed on material cut from recently reseeded perennial ryegrass and extensively managed permanent pasture. In each experimental period, individual ad libitum dry matter intake (DMI) was determined indoors following an adaptation period of 2 weeks, and $\mathrm{CH}_{4}$ emissions were measured individually in open-circuit respiration chambers over a period of 3 days. Although total daily $\mathrm{CH}_{4}$ emissions were lower for the WM lambs than for the TexX lambs $(13.3 \mathrm{v} .15 .7 \mathrm{~g} /$ day, respectively) when offered fresh forage, the yield of $\mathrm{CH}_{4}$ per unit DMI was similar for the two breed types (16.4 v. $\left.17.7 \mathrm{~g} \mathrm{CH}_{4} / \mathrm{kg} \mathrm{DMI}\right)$. Total output of $\mathrm{CH}_{4}$ per day was higher when lambs were offered ryegrass compared with permanent pasture ( $16 \cdot 1 \mathrm{v} .12 .9 \mathrm{~g} /$ day, respectively), which was probably driven by differences in DMI (986 v. $732 \mathrm{~g} /$ day). Methane emissions per unit DMI $(16 \cdot 4 \mathrm{v}$. $\left.17.7 \mathrm{~g} \mathrm{CH}_{4} / \mathrm{kg} \mathrm{DMI}\right)$ and proportion of gross energy intake excreted as $\mathrm{CH}_{4}(0.052$ v. $0.056 \mathrm{MJ} / \mathrm{MJ})$ were both higher on the permanent pasture. No forage $\times$ breed type interactions were identified. The results indicate that forage type had a greater impact than breed type on $\mathrm{CH}_{4}$ emissions from growing weaned lambs. It can be concluded that when calculating $\mathrm{CH}_{4}$ emissions for inventory purposes, it is more important to know what forages growing lambs are consuming than to know what breeds they are.

\section{INTRODUCTION}

The livestock sector faces major challenges in reducing its contribution to global environmental problems (Steinfeld et al. 2006). At the same time livestock numbers are increasing across the globe in response to rising demand for meat and dairy products, with sheep numbers forecast to increase by $60 \%$ to 2050 (Foresight 2010). According to the UK's 2012 greenhouse gas (GHG) inventory returns, agriculture was the source of about 0.44 of total UK emissions of methane $\left(\mathrm{CH}_{4}\right)$, and of this c. 0.70 came from livestock enteric sources (mostly ruminants) (DECC 2014). Sheep meat makes up $0 \cdot 10$ of the total meat produced and consumed in the UK, but according to available data sheep account

* To whom all correspondence should be addressed. Email: mdf@ aber.ac.uk for over 0.16 of the GHG emissions from UK livestock species (DECC 2014). Improving the precision of emission data reporting is essential in order to identify key factors influencing the emission rates from different livestock systems and subsequently assessing the effectiveness of mitigation strategies. The current UK National GHG Inventory reports baseline emissions from sheep to the United Nations Framework Convention on Climate Change (UNFCCC) uses the most simplified approach to accounting (Tier 1 ) and relies on default emission factors (EFs) published by the Intergovernmental Panel on Climate Change (IPCC) (Dong et al. 2006). However, many of the observational data that these have been based upon have been collected from breeds or forages unrepresentative of pastures grazed by sheep within the UK and northern Europe (Murray et al. 1978; Ulyatt et al. 2002, 2005; Pinares-Patiño et al. 2003). 
In order to provide a robust basis for generating improved $\mathrm{EFs}$ for $\mathrm{CH}_{4}$ from sheep, baseline data are required for all stages of the production cycle. However, much of the sheep production in the UK is stratified into systems that utilize smaller, hardier breeds in the hills and heavier, more productive breeds and their crossbreds in the lowlands. It is possible that physiological and/or behavioural differences between different breed types may lead to differences in amounts of $\mathrm{CH}_{4}$ emitted. As part of a multi-centre research programme developing revised EFs for sheep and cattle the current experiment investigated the extent to which breed $\times$ diet relationships for growing lambs were explained solely by simple body weight and digestibility characteristics of the animal and diet, respectively, with no interactions. It quantified, for the first time, $\mathrm{CH}_{4}$ emissions from growing weaned lambs fed on pastures representative of those used in UK sheep production systems.

\section{MATERIALS AND METHODS}

\section{Experimental design}

The work described was conducted in accordance with the requirements of the UK Animals (Scientific Procedures) Act 1986 and with the approval of the Aberystwyth University Animal Welfare and Ethical Review Board. Data were collected in a 2 (breed) $\times 2$ (diet) Latin square cross-over design experiment. Measurements were made on lambs of contrasting breed types: (1) Welsh Mountain (WM, small, hardy, hill breed), and (2) Welsh Mule (WM $\times$ Bluefaced Leicester) $\times$ Texel (TexX, prime lamb) $(n=8$ per breed). The diets offered were: (1) herbage cut from an intensively managed ryegrass ley, and (2) herbage cut from an extensively managed, long-term permanent pasture

Eight ewe lambs of each breed type, aged c. 3 months old at the start of the experiment in June 2013, were selected from their respective flocks on the basis of live weight (LW) and body condition score (BCS) (MLC 2000) and pastured together on a mixed ryegrass/ clover sward until the experiment began. All animals were drenched with an anthelmintic prior to the start of each experimental period. Initially half the lambs of each breed type were grazed together on the ryegrass sward, and the other half on the permanent pasture. Following a minimum of 1 week of grazing at pasture the lambs were housed in group pens and zero-grazed on their respective forages. After a further acclimatization period of at least 1 week they were individually penned for 3 days, during which time feed intake was measured. They were then individually housed in one of four calibrated $\mathrm{CH}_{4}$ chambers (Gardiner et al. 2015) and data collected for 3 consecutive days from each individual animal. Within a given breed type, animals were assigned randomly to an initial forage treatment. Likewise, during each run animals were assigned randomly to individual $\mathrm{CH}_{4}$ chambers. Following completion of the first experimental period the animals were swapped to the other pasture type, and the procedure was repeated.

Forages offered

Two forages were offered to the lambs: (1) ryegrass, a recently sown ley of monoculture perennial ryegrass (Lolium perenne), and (2) a long-term ley of a mixture of grass and forb species. During the zerograzing period, when animals were inside in group pens, individual pens and $\mathrm{CH}_{4}$ chambers, forage was cut from the two pastures using a Haldrup plot harvester (J. Haldrup a/s, Løgstør, Denmark). Forage was cut three times per week and stored in a dark cool room at c. $4{ }^{\circ} \mathrm{C}$ prior to feeding. The lambs were fed on an ad libitum basis, with feed quantities designed to ensure a refusal margin of $0 \cdot 10-0 \cdot 15$ each day, with two equal portions offered at 09.00 and $16 \cdot 00 \mathrm{~h}$. Fresh water was continually available.

\section{Animal measurements}

The LW and BCS of the lambs was recorded prior to them entering the $\mathrm{CH}_{4}$ chambers and again as they were removed. Methane production was determined by comparing the $\mathrm{CH}_{4}$ concentrations in the air entering and leaving the chambers at a known rate of airflow. An eight port single channel $\mathrm{CH}_{4}$ gas analyser (MGA3000; ADC Gas Analysis Ltd, Hoddesdon, UK) was used to determine $\mathrm{CH}_{4}$ concentrations in ambient air and in the exhaust gas leaving each chamber on a rotational basis. Ambient gas was sampled from points between each pair of chambers. The $\mathrm{CH}_{4}$ analyser was set to take a reading for each location at the end of a 3-min sampling interval before moving on to the next source. Air flow data was captured using mini-vane anemometers (MiniVane6, Schiltknecht Messtechnik, Switzerland) at each chamber attached to a data logger (MSR145, MSR Electronics GmbH, Switzerland).

\section{Feed characterization}

The weights of feed offered and feed refused were recorded on a daily basis. Representative 
Table 1. Chemical composition of the forages offered. All values $\mathrm{g} / \mathrm{kg}$ DM unless otherwise stated

\begin{tabular}{lcrrr}
\hline \hline & & Permanent & \\
& Ryegrass & pasture & S.E.D. & $P$ value \\
\hline DM (g/kg FM) & 219 & 219 & $16 \cdot 5$ & $0 \cdot 974$ \\
Ash & 92 & 75 & $4 \cdot 9$ & $0 \cdot 004$ \\
CP & 133 & 118 & $10 \cdot 7$ & $0 \cdot 190$ \\
WSC & 226 & 118 & $17 \cdot 1$ & $<0 \cdot 001$ \\
NDF & 440 & 569 & $21 \cdot 6$ & $<0 \cdot 001$ \\
ADF & 242 & 318 & $11 \cdot 3$ & $<0 \cdot 001$ \\
DOMD & 731 & 593 & $24 \cdot 7$ & $0 \cdot 014$ \\
GE (MJ/kg DM) & $17 \cdot 3$ & $17 \cdot 7$ & $0 \cdot 040$ \\
\hline \hline
\end{tabular}

DM, dry matter; FM, fresh matter; CP, crude protein; WSC, water-soluble carbohydrates; NDF, neutral detergent fibre; ADF, acid detergent fibre; DOMD, digestible organic matter in the DM; GE, gross energy.

sub-samples of the material offered each day were oven-dried at $80^{\circ} \mathrm{C}$ to constant weight in order to determine dry matter (DM) content. A further sub-sample of the feed offered was collected at each feeding, bulked for each 3-day chamber period, and thoroughly mixed. Sub-samples were then taken to determine chemical and botanical composition. Sub-samples for chemical analysis were freeze-dried and milled through a $1 \mathrm{~mm}$ sieve. Ash was measured by igniting samples in a muffle furnace at $550{ }^{\circ} \mathrm{C}$ for $16 \mathrm{~h}$. Gross energy (GE), included because these values were used in subsequent calculations of $\mathrm{Y}_{\mathrm{m}}$ coefficients $\left(\mathrm{CH}_{4}\right.$-E/GE intake), was determined by adiabatic bomb calorimetry (Gallenkamp autobomb; Sanyo Gallenkamp PLC, Loughborough UK). Total nitrogen concentrations were determined using a Leco FP 428 nitrogen analyser (Leco Corporation, St. Joseph, MI, USA), and were expressed as crude protein (nitrogen $\times 6.25$ ). Watersoluble carbohydrate (WSC) concentrations were measured by an automated anthrone technique (Thomas 1977). Neutral detergent fibre (NDF) and acid detergent fibre were determined using the method of Van Soest et al (1991), adapted for the Gerhardt Fibrecap detergent system (FOSS UK Ltd, Warrington, UK). Digestibility of organic matter in the DM was determined using the two-stage pepsin-cellulase in-vitro method described by Jones \& Hayward (1975). In order to characterize botanical composition a sub-sample from the bulked material from each experimental run was separated into the following categories: ryegrass, unsown grasses, white clover (Trifolium repens), other forbs and dead material. All separated material was then dried to constant weight at $80^{\circ} \mathrm{C}$ and sward composition expressed on a proportional DM basis.
Data analysis

Metabolic live weight (MLW) was calculated as mean $\mathrm{LW}^{0 \cdot 75}$. Tier 1 (Dong et al. 2006) equivalent EFs (kg/year) were calculated as: $\mathrm{CH}_{4}$ (g/day) $\times 365$. Twoway analysis of variance with a blocking structure of chamber run/(animal $\times$ period) was used to investigate forage type $\times$ breed type interaction effects (Genstat 16; VSN International Ltd, Hemel Hempstead, UK).

\section{RESULTS}

Composition of the forages offered

Proportionally the ryegrass sward was made up of 0.92 perennial ryegrass, 0.02 unsown grasses and 0.06 dead material. In comparison the permanent pasture was more diverse. Only 0.05 of this sward was accounted for by perennial ryegrass, with unsown grasses (mainly Agrostis spp., Festuca spp., Poa spp and Holcus lanatus) making up 0.77 of the sward. Clover accounted for just under 0.04 of the sward, and other forb species for 0.03. This sward also contained a higher proportion of dead material $(0 \cdot 12)$.

The DM content of the two forages offered was similar, as was the crude protein concentration (Table 1). However, compared with the low-input permanent pasture the ryegrass had a higher WSC concentration, lower fibre concentrations and a higher digestibility.

Role of breed type and pasture type on voluntary intake and methane emissions

Although the lambs of the two breed types had the same BCS, as expected the smaller, native WM 
Table 2. Effect of breed type and pasture type on voluntary dry matter intake (DMI) and methane $\left(\mathrm{CH}_{4}\right)$ emissions by weaned lambs (where WM, Welsh Mountain; TexX, Texel cross; MLW, metabolic live weight)

\begin{tabular}{|c|c|c|c|c|c|c|c|}
\hline & \multicolumn{2}{|c|}{ Ryegrass } & \multicolumn{3}{|c|}{ Permanent pasture } & \multicolumn{2}{|c|}{$P$ value* } \\
\hline & WM & TexX & WM & TexX & S.E.D. & Breed & Pasture \\
\hline Weight of lambs at start $(\mathrm{kg})$ & 27 & 35 & 26 & 34 & $1 \cdot 2$ & $<0 \cdot 001$ & $0 \cdot 307$ \\
\hline DMI (g/day) & 931 & 1041 & 705 & 758 & $74 \cdot 7$ & $0 \cdot 275$ & $<0 \cdot 001$ \\
\hline DMI (g/kg MLW) & 78 & 73 & 61 & 53 & $4 \cdot 7$ & $0 \cdot 168$ & $<0 \cdot 001$ \\
\hline $\mathrm{CH}_{4}$ emitted (g/day) & 15 & 17 & 12 & 14 & $1 \cdot 1$ & 0.035 & $<0 \cdot 001$ \\
\hline $\mathrm{CH}_{4}$ emitted (g/kg MLW) & $1 \cdot 2$ & $1 \cdot 2$ & $1 \cdot 0$ & $1 \cdot 0$ & 0.07 & $0 \cdot 651$ & $<0 \cdot 001$ \\
\hline $\mathrm{CH}_{4}$ emitted (g/kg DMl) & $16 \cdot 1$ & $16 \cdot 7$ & $16 \cdot 7$ & $18 \cdot 8$ & 0.87 & $0 \cdot 116$ & 0.004 \\
\hline $\mathrm{CH}_{4}$ emitted (kg/year) $\dagger$ & $5 \cdot 4$ & $6 \cdot 3$ & $4 \cdot 3$ & $5 \cdot 1$ & 0.41 & 0.035 & $<0 \cdot 001$ \\
\hline $\mathrm{CH}_{4}$-E/GE intake $(\mathrm{MJ} / \mathrm{MJ})$ & $0 \cdot 052$ & $0 \cdot 054$ & 0.053 & $0 \cdot 059$ & $0 \cdot 0028$ & $0 \cdot 120$ & $0 \cdot 018$ \\
\hline
\end{tabular}

GE, gross energy

* There were no significant interaction effects.

+ Estimated using the Tier 1 approach (Dong et al. 2006).

lambs were significantly lighter than the TexX lambs at the start of the experiment despite being approximately the same age (Table 2). While total daily $\mathrm{CH}_{4}$ emissions were higher for the TexX lambs compared with the WM lambs, the yield of $\mathrm{CH}_{4}$ per unit of forage consumed was similar for the two breed types, as was the yield per unit MLW.

Pasture type had a highly significant effect on daily $\mathrm{CH}_{4}$ emissions (Table 2), in turn influencing the EFs estimated using the Tier 1 approach (Dong et al. 2006). Total output of $\mathrm{CH}_{4}$ per day was higher when offered ryegrass, but DMI was also higher on this forage type. The $\mathrm{CH}_{4}$ yield per unit of forage consumed and $\mathrm{CH}_{4}$ energy excreted per unit GE intake $\left(\mathrm{Y}_{\mathrm{m}}\right)$ were higher for lambs consuming the permanent pasture. No forage type $\times$ breed type interactions were identified.

\section{DISCUSSION}

The current experiment explored the potential for breed type and pasture type to influence enteric $\mathrm{CH}_{4}$ emissions from growing lambs. Data were collected for weaned lambs offered material from swards representative of the pastures used by commercial producers at the corresponding stage of the sheep production cycle. There are relatively few previous studies that have reported emissions for sheep $<1$ year old, and the majority of these have been based on animals aged 7-12 months, i.e. store lambs rather than finishing lambs.

Influence of breed type

While the potential to exploit within-breed variation in $\mathrm{CH}_{4}$ emissions within genetic improvement programmes has been recognized (Pinares-Patiño et al. 2011; Lambe et al. 2014), there is little information available regarding the extent to which $\mathrm{CH}_{4}$ emissions vary between different breeds of sheep. For the current experiment two contrasting breed types of lamb were chosen. The WM is a hardy hill breed adapted to survive on low-quality forage in the exposed conditions of upland Wales. They play an important role in the stratified sheep industry within the UK because as well as producing purebred hill lambs WM ewes are popular for crossing with longwool rams to produce the type of larger crossbred ewe ('mules' and 'halfbreds') commonly used for fat lamb production (Pollott 2014). The TexX lambs were representative of the output from this final cross, in which a terminal sire such as the Texel is used to produce prime lamb meat (Pollott 2014).

Overall, breed type was found to have a limited role in influencing $\mathrm{CH}_{4}$ emissions. While the TexX lambs produced more $\mathrm{CH}_{4}$ per day, the amounts produced by the two different breed types was similar on a per unit intake and per unit MLW basis. Recent experiments in which measurements were made on different breed types of hill (Aubry et al. 2014a) and lowland (Aubry et al. 2014b) replacement ewes aged from 8 to 19 months also found no difference in $\mathrm{CH}_{4}$ emissions as a proportion of feed intake. It was not possible to measure LW gain meaningfully within the current experimental design, but prime lambs such as the TexX lambs would be expected to be growing faster and reach slaughter weight earlier than purebred hill lambs (Carson et al. 2001). Consequently, although the $\mathrm{CH}_{4}$ emissions per day may be higher for these 
Table 3. Estimated enteric fermentation emission factors (EF) for sheep. The ryegrass and permanent pasture values were generated based on measured mean emission rates per day for Welsh Mountain and Texel cross lambs aged 3-4 months old

\begin{tabular}{llc}
\hline \hline & EF & Reference \\
\hline Published & & \\
Mature sheep (>1 year old) & $8 \cdot 0 \mathrm{~kg} \mathrm{CH}_{4} /$ head/year & Dong et al. (2006) \\
UK Lambs* & $2 \cdot 2 \mathrm{~kg} \mathrm{CH}_{4} /$ head/year & \\
Current study & & \\
Ryegrass (for 12 month period) & $5.9 \mathrm{~kg} \mathrm{CH}_{4} /$ head/year & \\
Permanent pasture (for 12 month period) & $4.7 \mathrm{~kg} \mathrm{CH}_{4} /$ head/year & \\
Ryegrass (for $8 \cdot 1$ month lifespan) & $4 \cdot 0 \mathrm{~kg} \mathrm{CH}_{4} /$ head/year & \\
Permanent pasture (for $8 \cdot 1$ month lifespan) & $3 \cdot 2 \mathrm{~kg} \mathrm{CH}_{4} /$ head/year & \\
\hline \hline
\end{tabular}

Methane, $\mathrm{CH}_{4}$

* Assumes emission factor is $0 \cdot 4$ of that of an adult sheep and the average lifespan of lambs is $8 \cdot 1$ months.

animals, emissions intensity in terms of $\mathrm{CH}_{4}$ per unit weight gain would be expected to be lower.

\section{Influence of pasture type}

Studies with lambs to date have largely focussed on the effects of selected dietary ingredients and additives (Molano et al. 2008; Mao et al. 2010; Li et al. 2012, 2013; Avila-Stagno et al. 2013; Barnett \& Hegarty 2014; El-Zaiat et al. 2014). The role of different pasture types has been limited to comparisons of grass and white clover (Hammond et al. 2011). The current study found that pasture type had a much stronger influence on $\mathrm{CH}_{4}$ emissions than lamb breed type. The pastures chosen for the experiment were typical of sward types grazed by comparatively intensively (re-seeded ryegrass) and extensively (permanent pasture) produced lambs during the postweaning period. The main differences in nutritional value related to the concentrations of WSC and fibre within the forages, and related effects on digestibility. In turn these differences will likely have influenced voluntary feed intake, with the significantly lower DMIs for lambs offered the permanent pasture probably being due to longer rumen retention times (Thornton \& Minson 1973). An increase in NDF concentration has been shown to increase $\mathrm{CH}_{4}$ yield (g $\mathrm{CH}_{4} / \mathrm{kg}$ DM intake) for dairy cattle (Yan et al. 2009), and the results obtained for growing lambs in the current trial reflect this relationship. In contrast, Hammond et al. (2011) found no difference in $\mathrm{CH}_{4}$ yield from older (1-2 years) sheep offered fresh white clover or perennial ryegrass, despite marked differences in chemical composition of the forages.
Inventory and industry applications

The current approach to the UK GHG inventory is to assume the IPCC Tier 1 default EF for enteric fermentation for all mature sheep (i.e. >1 year old; Dong et al. 2006). Lambs have a lower average LW than mature sheep and the majority have a lifespan of $<12$ months, and would be expected to be associated with a lower EF than mature sheep. The UK therefore uses a country-specific EF for enteric fermentation for lambs at $40 \%$ of that of an adult sheep together with a reduction factor reflecting the reduced lifespan of lambs (Webb et al. 2013), which is estimated as $8 \cdot 1$ months. No adjustment is made for the pre-weaning period. The equivalent EFs calculated from the daily emission rates for the lambs in the current study are higher than the value estimated by Webb et al. (2013) (Table 3). In situations where finishing lambs are supplemented with concentrate feeds the $\mathrm{CH}_{4}$ emissions would be expected to be reduced, as such animals should produce less $\mathrm{CH}_{4}$ per day (Gill et al. 2010) and have a shorter time to finish. However, poor economic returns from sheep production mean that most farmers are keen to avoid the additional costs associated with supplementary feeding. The overall treatment mean for $\mathrm{Y}_{\mathrm{m}}$ of $0.054 \mathrm{MJ} / \mathrm{MJ}$ is lower than the IPCC Tier 1 value for sheep of 0.065 $\mathrm{MJ} / \mathrm{MJ}$ (Dong et al. 2006). This means that $\mathrm{CH}_{4}$ emissions for growing lambs are likely to be lower than currently calculated using the default IPCC Tier 1 methodology because a lower proportion of the GE consumed would be lost from the rumen as $\mathrm{CH}_{4}$.

The current study provides an emissions benchmark against which mitigation targets can be set and 
progress measured. It also provides representative data for use in wider comparisons of environmental impact. For example, carbon footprinting is increasingly used in the food supply chain to estimate the quantity of GHG emitted at different stages of the production process (Edwards-Jones et al. 2009; Jones et al. 2014). Enteric $\mathrm{CH}_{4}$ emissions are estimated to contribute to over $40 \%$ of the mean footprint (Jones et al. 2014), but current calculations are based upon the default IPCC EFs. By refining input data and EFs the precision of carbon footprint models can be improved both spatially and temporally and uncertainty in the carbon footprint estimate reduced (Basset-Mens et al. 2009).

\section{CONCLUSIONS}

Although total daily $\mathrm{CH}_{4}$ emissions were higher for the prime lambs compared with the smaller hill lambs when offered fresh forage, the yield of $\mathrm{CH}_{4}$ per unit intake was similar for the two breed types. The total output of $\mathrm{CH}_{4}$ per day was higher when offered ryegrass compared with permanent pasture, but $\mathrm{CH}_{4}$ emissions per unit intake and $Y_{m}$ were higher on the permanent pasture. Overall the results indicate that forage type has a greater impact than breed type on $\mathrm{CH}_{4}$ emissions from weaned lambs.

This work was funded by Defra, the Scottish Government, DARD and the Welsh Government as part of the UK's Agricultural GHG Research Platform.

\section{REFERENCES}

Aubry, A., Annett, R. \& YAN, T. (2014a). Effects of breed and forage types on methane emission factors for hill replacement ewes aged between 9 and 18 months. Advances in Animal Biosciences 5, Part 1, 29.

Aubry, A., ANNEtT, R. \& YAN, T. (2014b). Effects of breed and forage types on methane emission factors for lowland replacement ewes aged between 8 and 19 months. Advances in Animal Biosciences 5, Part 1, 25

Avila-Stagno, J., Chaves, A. V., He, M. L., Harstad, O. M., Beauchemin, K. A., McGinn, S. M. \& McAllister, T.A. (2013). Effects of increasing concentrations of glycerol in concentrate diets on nutrient digestibility, methane emissions, growth, fatty acid profiles, and carcass traits of lambs. Journal of Animal Science 91, 829-837.

Barnett, M. C. \& Hegarty, R. S. (2014). Cysteamine hydrochloride increases bodyweight and wool fibre length, improves feed conversion ratio and reduces methane yield in sheep. Animal Production Science 54, 12881293.
Basset-Mens, C., Kelliher, F. M., Ledgard, S. \& Cox, N. (2009). Uncertainty of global warming potential for milk production on a New Zealand farm and implications for decision making. International Journal of Life Cycle Assessment 14, 630-638.

CARSON, A. F., IRWIN, D. \& KilPATRICK, D. J. (2001). A comparison of Scottish Blackface and Cheviot ewes and five sire breeds in terms of lamb output at weaning in hill sheep systems. Journal of Agricultural Science, Cambridge 137, 221-233.

DECC (2014). 2012 UK Greenhouse Gas Emissions, Final Figures. London: HMSO.

Edwards-Jones, G., Plassmann, K. \& Harris, I. M. (2009). Carbon footprinting of lamb and beef production systems: insights from an empirical analysis of farms in Wales, UK. Journal of Agricultural Science, Cambridge 147, 707-719.

El-Zaiat, H. M., Araujo, R. C., Soltan, Y. A., Morsy, A. S., Louvandini, H., Pires, A. V., Patino, H. O., Correa, P. S. \& AbDalla, A. L. (2014). Encapsulated nitrate and cashew nut shell liquid on blood and rumen constituents, methane emission, and growth performance of lambs. Journal of Animal Science 92, 2214-2224.

Foresight (2010). Foresight Land Use Futures Project: Final Project Report. London: The Government Office for Science.

Gardiner, T. D., Coleman, M. D., Innocenti, F., Tompkins, J., Connor, A., Garnsworthy, P.C., Moorby, J.M., Reynolds, C. K., Waterhouse, A. \& Wills, D. (2015). Determination of the absolute accuracy of UK chamber facilities used in measuring methane emissions from livestock. Measurement 66, 272-279.

Gill, M., Smith, P. \& Wilkinson, J. M. (2010). Mitigating climate change: the role of domestic livestock. Animal 4, 323-333.

Hammond, K. J., Hoskin, S. O., Burke, J. L., Waghorn, G. C., KoOlaARD, J.P. \& Muetzel, S. (2011). Effects of feeding fresh white clover (Trifolium repens) or perennial ryegrass (Lolium perenne) on enteric methane emissions from sheep. Animal Feed Science and Technology 166-67, 398-404.

Dong, H., Mangino, J., McAllister, T.A., Hatfield, J. L., Johnson, D. E., LASSEY, K. R., Aparecida DE Lima, M. \& ROMANOVSKAYA, A. (2006). Emissions from livestock and manure management, chapter 10. In Guidelines for National Greenhouse Gas Inventories, Vol 4: Agriculture, Forestry and Other Land Uses (Eds H.S. Eggleston, L. Buendia, K. Miwa, T. Ngara \& K. Tanabe), pp. 10.1-10.87. Prepared by the National Greenhouse Gas Inventories Programme. Hayama, Japan: IGES.

JONES, A. K., JONES, D. L. \& CROSS, P. (2014). The carbon footprint of lamb: sources of variation and opportunities for mitigation. Agricultural Systems 123, 97-107.

JONES, D. I. H. \& HAYwARD, M. V. (1975). The effect of pepsin pretreatment of herbage on the prediction of dry matter digestibility from solubility in fungal cellulase solutions. Journal of the Science Food and Agriculture 26, 711-718.

Lambe, N. R., Wall, E., Ludemann, C.I., Bünger, L. \& Conington, J. (2014). Genetic improvement of hill sheep - impacts on profitability and greenhouse gas emissions. Small Ruminant Research 120, 27-34. 
LI, L., Davis, J., Nolan, J. \& Hegarty, R. (2012). An initial investigation on rumen fermentation pattern and methane emission of sheep offered diets containing urea or nitrate as the nitrogen source. Animal Production Science 52, 653-658.

LI, L., Silveira, C. I., Nolan, J. V., Godwin, I. R., LenG, R. A. \& HeGARTY, R. S. (2013). Effect of added dietary nitrate and elemental sulfur on wool growth and methane emission of Merino lambs. Animal Production Science 53, 11951201.

MaO, H.-L., WanG, J.-K., ZhOU, Y.-Y. \& LiU, J.-X. (2010). Effects of addition of tea saponins and soybean oil on methane production, fermentation and microbial population in the rumen of growing lambs. Livestock Science 129, 56-62.

MLC (2000). Planned Carcase Production. Sheep Management Matters, No.8. Milton Keynes, UK: Meat and Livestock Commission.

Molano, G., KNiGht, T. W. \& Clark, H. (2008). Fumaric acid supplements have no effect on methane emissions per unit of feed intake in wether lambs. Australian Journal of Experimental Agriculture 48, 165-168.

Murray, R. M., Bryant, A. M. \& Leng, R. A. (1978). Methane production in the rumen and lower gut of sheep given lucerne chaff: effect of level of intake. British Journal of Nutrition 39, 337-345.

Pinares-Patiño, C. S., Ulyatt, M. J., Waghorn, G. C., Lassey, K. R., Barry, T. N., Holmes, C. W. \& Johnson, D. E. (2003). Methane emission by alpaca and sheep fed on lucerne hay or grazed on pastures of perennial ryegrass/white clover or birdsfoot trefoil. Journal of Agricultural Science, Cambridge 140, 215-226.

Pinares-Patiño, C. S., McEwan, J. C., Dodds, K. G., Cárdenas, E. A., Hegarty, R.S., Koolaard, J.P. \& ClARK, H. (2011). Repeatability of methane emissions from sheep. Animal Feed Science and Technology 166-67, 210-218.
Pollott, G. (2014). The Breeding Structure of the British Sheep Industry 2012: Results of the 2012 Survey of Sheep Breeds in Great Britain. Kenilworth, UK: EBLEX.

Steinfeld, H., Gerber, P., Wassenaar, T., Castel, V., Rosale, M. \& De HaAn, C. (2006). Livestock's Long Shadow: Environmental Issues and Options. Rome, Italy: FAO.

Thomas, T. A. (1977). An automated procedure for the determination of soluble carbohydrates in herbage. Journal of the Science of Food and Agriculture 28, 639-642.

Thornton, R. F. \& Minson, D. J. (1973). The relationship between apparent retention time in the rumen, voluntary intake, and apparent digestibility of legume and grass diets in sheep. Australian Journal of Agricultural Research 24, 889-898.

Ulyatt, M. J., Lassey, K. R., Shelton, I. D. \& Walker, C. F. (2002). Methane emission from dairy cows and wether sheep fed subtropical grass-dominant pastures in midsummer in New Zealand. New Zealand Journal of Agricultural Research 45, 227-234.

Ulyatt, M. J., Lassey, K. R., Shelton, I. D. \& Walker, C. F. (2005). Methane emission from sheep grazing four pastures in late summer in New Zealand. New Zealand Journal of Agricultural Research 48, 385-390.

Van Soest, P.J., Robertson, J. B. \& Lewis, B. A. (1991). Methods for dietary fibre, neutral detergent fibre and nonstarch polysaccharides in relation to animal nutrition. Journal of Dairy Science 74, 3583-3597.

Webb, N., Broomfield, M., Cardenas, L., MacCarthy, J., Murrels, T., Pang, Y., Passant, N., Thistlethwaite, G. \& Thomson, A. (2013). UK Greenhouse Gas Inventory 1990 to 2011: Annual Report for Submission under the Framework Convention on Climate Change. RicardoAEA/R/3355. London: HMSO.

Yan, T., Porter, M. G. \& Mayne, S. C. (2009). Prediction of methane emission from beef cattle using data measured in indirect open-circuit respiration calorimeters. Animal 3, 1455-1462. 